Japanese Journal of Herpetology 11(4):161-166. 1986.

\title{
Histochemical Studies on the Lingual Glands of The Japanese Red-Bellied Newt, Cynops pyrrhogaster pyrrhogaster
}

\author{
Shingo KURABUCHI*
}

\begin{abstract}
From the histochemical analysis of the tongue of Cynops pyrrhogaster pyrrhogaster, it has been possible to establish that the lingual glands and the goblet cells show a variety of cellular types which display typical histochemical reaction to mucopolysaccharides and proteins. In the terminal portions of the lingual glands every cell produces secretory granules consisting of mucopolysaccharides and proteins, but in the cervical portions the secretory cells contain hardly any protein substance. The goblet cells scattered on the ventral epithelium contain both neutral and acid mucopolysaccharides.
\end{abstract}

\section{INTRODUCTION}

The tongues of amphibians are of various characteristic forms and functions according to their orders and families. In feeding, some species extend the tongue to catch food (Bufoidae and Ranidae etc., anuran amphibians) and some bite or absorb food probably without the support of a tongue (urodela amphibians). The anuran species in the family Pipidae, which live in the water throughout their life, lack a tongue. As has been well known for a long time, the tongues of amphibians have lingual glands which are either well developed or not. Some histological and histochemical studies have shown that these glands differ somewhat in structure among families or species and that the secretory substances vary greatly. There are those of a mucous nature (Nalavade and Varute, 1971), serous nature (Nalavade and Varute, 1971), muco-serous nature (Albanese Carmignani and Zaccone, 1974, 1977 ; Francis, 1961; Albanese Carmignani et al., 1975; Zylberberg, 1972, 1973), and sero-mucous nature (Albanese Carmignani et al., 1975). On the other hand, Nalavade and Varute (1972) have described two types of goblet cells scattered in the epithelium of the tongue containing neutral or acid mucopolysaccharides.

Hence, in view of a certain variation in secretory cell types found in the lingual glands and goblet cells in the species of amphibians examined, especially from the histochemical point of view, I think the tongues of the other species of amphibians, especially of the urodela on which only few studies have been reported, should continue to be studied.

*Department of Histology, Nippon Dental University, 1-9-20 Fujimi, Chiyoda-ku, Tokyo, 102 Japan. 102 東京都千代田区富士見 1 丁目 9 番 20 号 日本歯科大学解剖学教室第 II 講座 


\section{MATERIALS AND METHODS}

Japanese red-bellied newts, Cynops pyrrhogaster pyrrhogaster, collected in Niigata Prefecture were used in the present observations. The jaws with tongues were dissected out from decapitated animals and immersed in various fixative solutions (Table 1). The tongues were then cut out and embedded in paraplast, JB4, or epon 812. For epon 812 sections, all stainings were performed after removing the resin according to Imai et al. (1968). The stains used for the preliminary structural study were as follows: Mayer's hematoxylin-eosin, Azan, Masson-Goldner and Heidenhain's iron hematoxylin. For the histochemical study, the following methods were used. Proteins: naphthol yellow S test of Meek (1962); ninhydrin-Schiff test of Yasuma and Ichikawa (1953). Neutral polysaccharides: periodic acid Schiff (PAS) test of McManus (1948). Acid mucopolysaccharides: staining with Alcian blue $8 \mathrm{GX}$ at $\mathrm{pH}$ 2.5. according to Mowry (1960). Lipids: cryostat frozen sections stained with Sudan III (Daddi, 1896), Sudan IV (Seki, 1961), and Oil Red O (Lillie, 1944). These staining methods are described in the textbook "SOSHIKIGAKU" (Sano, 1972).

\section{RESULTS}

The tongue of the newts examined was not well developed and upheaved on the mandibula. The lingual glands were observed mainly to be of the branched or single tubular type, opening to the dorsal surface of the stratified epithelium of the tongue and some terminal portions penetrated deeply into the layer of the tongue muscle to reach under the hypohycal cartilage and a number of gland entangled to form a large group (Fig. 1). Preliminary stainings showed the cells of the terminal portions of the lingual glands to be probably of the muco-serous type, the cells containing not only mucous-type stains but also many small serous-like granules stained with heme-toxylin ( $\mathrm{H}-\mathrm{E}$ stain), azocarmine $\mathrm{G}$ (Azan stain, Fig. 2-A), ponceau de xylidine (Masson-Goldner stain), and iron hematoxylin (Fig. 2-B). The cervical portions of the lingual glands near or in the epithelium showed only mucous stains. In these secretory cells, the nucleus was located in the periphery in the same manner as the goblet cells scattered in the tongue epithelium.

The results of these histochemical procedures, which are summarized in Table 1, showed clearly that the cells of the terminal portions in every lingual gland contained protein. Small secretory granules were observed by the staining methods for protein: naphthol yellow S (Fig. 2-C) and red purple ninhydrin-Schiff reacted in the cytoplasm. Again, PAS reactions for neutral mucopolysaccharide, not glycogen, were very strong (Fig. 2-D). The same positionswere stained with Alcian blue, though the reaction was very weak (Fig. 2-E). 'Thus, the cells of the terminal portions were of a muco-serous type. But in the cervical portions 


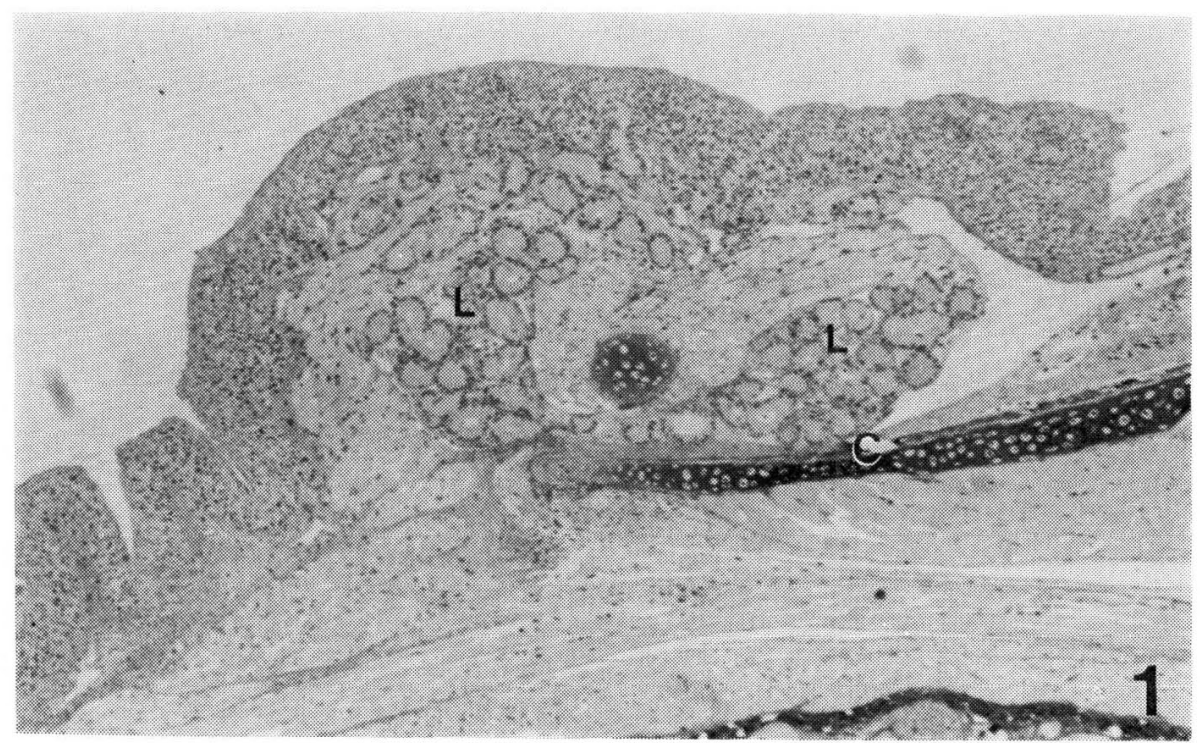

Fig. 1. Longitudinal section of tongue rose on the mandibula, showing lingual glands (L) forming a group on the hypohycal cartilage (C). HE stain. $\times 30$.

Table 1. Results of histochemical procedures.

Four categories were classified: negative $(-)$, positive $(+)$ and strong $(++$ or +++$)$.

\begin{tabular}{|c|c|c|c|c|c|}
\hline \multirow{2}{*}{$\begin{array}{l}\text { Histochemical } \\
\text { Pocedures }\end{array}$} & \multirow{2}{*}{ Fixation* } & \multirow{2}{*}{ Section** } & \multirow{2}{*}{$\begin{array}{l}\text { Goblet } \\
\text { Cells }\end{array}$} & \multicolumn{2}{|c|}{ Lingual Gland } \\
\hline & & & & Cervix & Terminal \\
\hline 1. Naphtol YS & $\mathrm{F}, \mathrm{BH}$ & $\mathrm{P}, \mathrm{J}, \mathrm{E}$ & - & - & ++ \\
\hline 2. Ninhydrin-Schiff & $\mathrm{F}, \mathrm{BH}$ & $\mathrm{P}, \mathrm{J}$ & - & - & + \\
\hline 3. PAS & $\mathrm{C}, \mathrm{BH}$ & $\mathrm{P}, \mathrm{J}, \mathrm{E}$ & ++ & ++ & ++ \\
\hline 4. Alcian Blue & $\mathrm{C}, \mathrm{BH}$ & $\mathrm{P}, \mathrm{J}, \mathrm{E}$ & +++ & ++ & + \\
\hline 5. PAS-AB*** & $\mathrm{C}, \mathrm{BH}$ & $\mathrm{J}, \mathrm{E}$ & $\mathrm{PAS}<\mathrm{AB}$ & $\mathrm{PAS}<\mathrm{AB}$ & $\mathrm{PAS}>\mathrm{AB}$ \\
\hline 6. Diastase-PAS & $\mathrm{C}$ & $\mathrm{P}, \mathrm{J}$ & ++ & ++ & ++ \\
\hline 7. Sudan III & $\mathrm{Ca}-\mathrm{F}$ & Cry & - & - & - \\
\hline 8. Sudan IV & $\mathrm{Ca}-\mathrm{F}$ & Cry & - & - & - \\
\hline 9. Oil Red O & $\mathrm{Ca}-\mathrm{F}$ & Cry & - & - & - \\
\hline
\end{tabular}

*Fixation; 10\% Formalin (F), Bouin-Holland (BH), Carnoy (C) and cold $2 \% \mathrm{CaCl}_{2}$ in $10 \%$ Formalin $(\mathrm{CaF})$.

**Section; Paraplast $-5 \mu \mathrm{m}(\mathrm{P})$, JB4- $2 \mu \mathrm{m}(\mathrm{J})$, Epon $812-2 \mu \mathrm{m}(\mathrm{E})$ and frozen Cryostat $-8 \mu \mathrm{m}$ sections (Cry).

***Intensively stained colours compared (PAS and Alcian blue).

the secretory substances were mainly neutral and acid mucopolysaccharides and contained scarcely any protein. The goblet cells scattered in the tongue epithelium were found to be a mucous type from the results of the PAS reaction and 

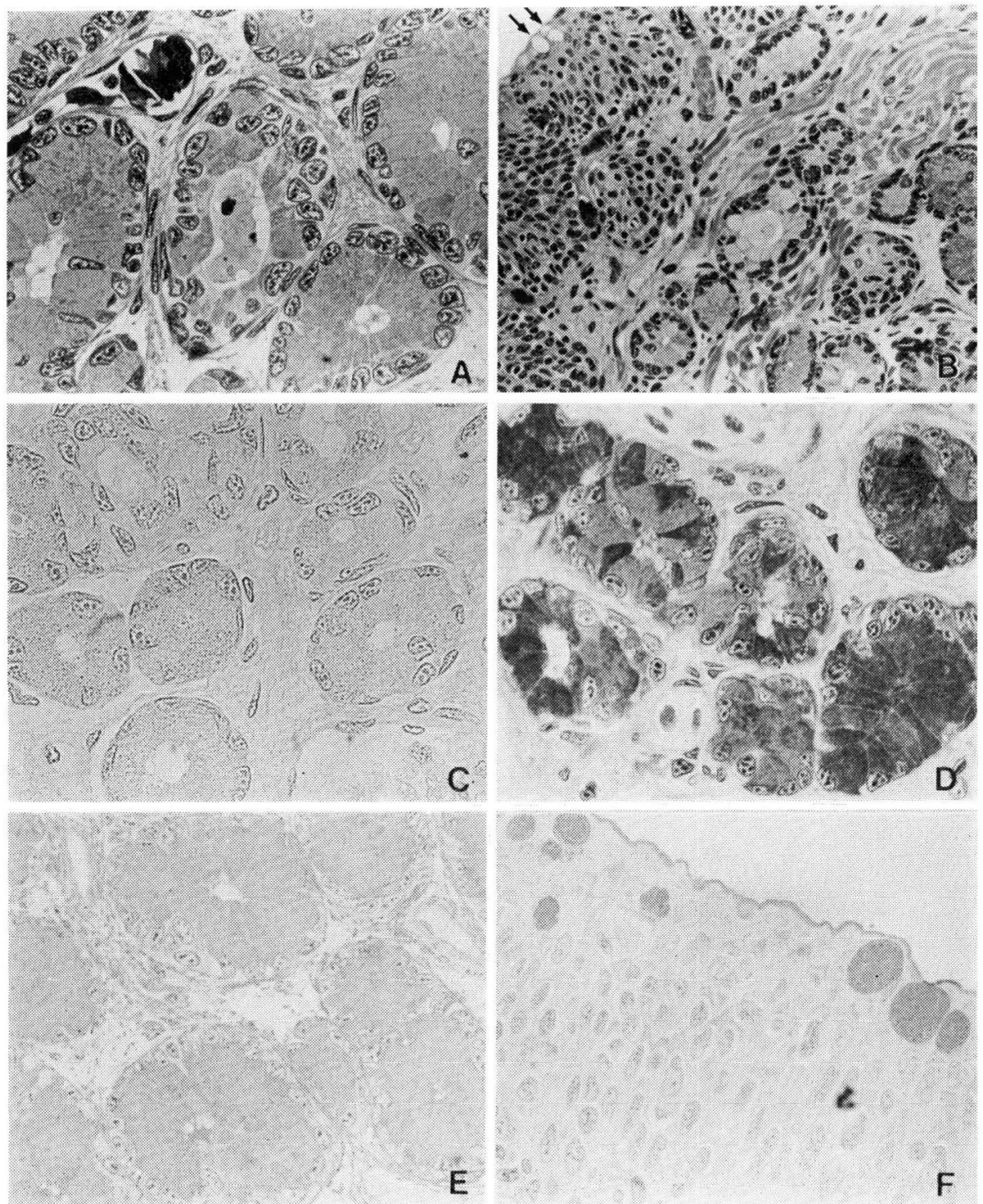

Fig. 2. A: Terminal portions of lingual glands. The cytoplasm of every cell was stained blue and small red grains were distributed in them. Azan stain. $\times 190$. B: Goblet cells (arrows) in the epithelium were not stained but small dark blue grains were densely distributed in the terminal portions of the lingual glands. Heidenhain's iron hematoxylin stain. $\times 70$. C-E: Staining reactions of histochemical procedures in the terminal portions of the lingual glands. C: Naphtol yellow S test. Many small yellow grains were detected in the cytoplasm. $\times 180$. D: PAS reaction poststained with hematoxylin. The cytoplasm was stained red. $\times 180)$ E $: A B$ reaction $\left(\mathrm{pH}^{-}=2.5\right)$ poststained with hematoxylin. The cytoplasm was stained faint blue. $\times 180$. $\mathrm{F}$ : $\mathrm{AB}$ reaction $(\mathrm{PH}=2.5)$ poststained with hematoxylin. The goblet cells in the epithelium were stained deep blue. $\times 180$. 
Alcian blue stain (Fig. 2-F). Especially the cells contain acid mucopolysacchride in large quantities in contrast to the cells of lingual glands stained with Alcian blue staining (Table 1 ).

As a result of the staining with Sudan III, IV and oil red O, lipid droplets were observed in the connective tissue under the epithelium but were not detected in the cells of any secretory gland in the newt tongue.

\section{DISCUSSION}

As has been reported concerning several species of amphibians, the lingual glands showed several types of structures: crypt, nonbranched tubular, acinous, or branched tubular, and generally these glands are more developed in urodeles than in anura (Saegusa, 1970). As found in other species of urodela (Saegusa, 1970; Zyberberg, 1972, 1973), in Cynops pyrrhogaster pyrrhogaster, the lingual glands were of a simple branched tubular type and all the glands were entangled to form a group deep in the tongue.

From the histochemical observations previously reported, the amphibian lingual glands showed polysomatic aspects in every species and family: mucous, serous, muco-serous and sero-mucous, mainly studied in anuran amphibians (Albanese Carmignani and Zaccone, 1974, 1975; Nalavade and Varute, 1971, 1972; Albanese Carmignani et al., 1975). The present histochemical study on the newt lingual glands revealed that the secretory cells in the terminal portions contain neutral mucopolysaccharide, but not glycogen, and proteins, with a small quantity of acid mucopolysaccharide, though in the cervical portions protein was almost entirely lacking and only neutral and acid mucopolysaccharides were detected in the cells. That is to say, the newt lingual glands were of a muco-serous type, in agreement with what has already been asserted for the cells of the lingual glands in Salamandridae (Zylberberg, 1972, 1973). In some species of anurans the goblet cells in the ventral epithelium of the tongue were divided into two types: one containing neutral mucin and the other neutral and acid mucins (Nalavade and Varute, 1971; Albanese Carmignani and Zaccone, 1974), but in the present species only one type of goblet cell, containing neutral and acid mucopolysaccharides, was seen.

Regarding the function of these glands, Albanese Carmignani and Zaccone (1974) estimated that the presence of acid mucopolysaccharide affected the physiology of taste, as has been stated by various authors concerning other vertebrates (Scalzi, 1967; Francis, 1962). As is well known in anurans, the fungiform papilla plays a part in detecting taste, and its glandular cells in the crypt surrounding the papilla secrete a mucopolysaccharide associated with protein. In the newt which was the subject of the present study taste buds were observed in the dorsal surface of tongue, but the relationship between the taste bud and the lingual gland was obscure. Furthermore, the nature of the protein in the amphibian lingual glands is not known and this is a very interesting problem. 


\section{LITERATURE CITED}

Albanese Carmignani, M.P. and G. Zaccone. 1974. Mucopolysaccharide histochemistry of the lingual glands in Discoglossus pictus Otth. (Anuran Amphibian). Ann. Histochim. 19:47-63.

Albanese Carmignani, M.P. and G. Zaccone. 1977. Histochemical studies on the tongue of anuran amphibians-II. Comparative morphochemical study of the taste buds and the lingual glands in $B u f o$ viridis Laurenti and Rana graeca Boulenger with particular reference to the mucosaccharide histochemistry. Cellular Molec. Biol. 22:203-217.

Albanese Carmignani, M.P., G. Zaccone and F. Cannata. 1975. Histochemical studies on the tongue of anuran amphibians-I. Mucopolysaccharide histochemistry of the papillae and the lingual glands in Hyla arborea L., Rana esculenta L. and Bufo vulgaris Laur. Ann. Histochem. 20:47-65.

Francis Eric, T.B. 1962. The sources and nature of salivary secretions in Amphibia. Proc. Zool. Soc. Lond. 38:115-210.

Imai, Y., A. Sue and A. Yamaguchi. 1968. A removing method of the resin from epoxy-embedded sections for light microscopy. J. Electron Microsc. 17:84-85.

Nalavade, M.N. and A.T. Varute. 1971. Histochemical studies on the mucins of the vertebrate tongues. I. Histochemical analysis of mucosubstances in the amphibian tongue. Histochemie $25: 351-365$.

Nalavade, M.N. and A.T. Varute. 1972. Histochemical studies on the mucins of the vertebrate tongues. II. Mucopolysaccharides in cells of taste-buds in tongues of tadpoles of Rana tigrina and Bufo melanosticus. Acta Hitochem. 43:202-210.

Saegusa, H. 1943. Comparative studies of salivary glands in several Japanese non-mammalian vertebrates. IGAKUKENKYU 18:313-359 (in Japanese).

Sano, Y. 1972. SOSHIKIGAKU. Nankodo Press, Tokyo (in Japanese).

Scalzi, H.A. 1967. The cytoarchitecture of gustatory receptors from the rabbit foliate papilae. $Z$. Zellforsch. Mikroskop. 12:44-45.

Zylberlberg, L. 1972. Données histologiques sur les glandes linguales d'Ichthyophis glutinosus (L.) (Batracien, Gymnophione). Arch. Anat. Micr. Morph. Exp., 61:227-242.

Zylberberg, L. 1973. Données histologiques sur les glandes de quelques Salamandrides (Batraciens, Urodeles). Arch. Biol. (Bruxelles) 84:341-366.

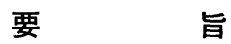

\section{アカラハイモリCynops pyrrhogaster pyrrhogaster の舌腺の組織化学}

\section{倉 淵 真 悟}

アカハライモリ舌腺の分泌物質の性状を知るために, 組織化学的染色法（盃白質：ナフトー ル黄 $\mathrm{S}$, ニンヒドリンーシッフ反応, 多糖類: 過ヨウ素酸ーシッフ反応, アリューシュン青 $(\mathrm{PH}$ 2.5)，脂質：ズダン III， IN，オイル赤O）を施した。イモリ舌腺は，主に単一分岐管状腺であ り，腺体部はもとより，開口部近くの腺頸部にも腺細胞が認められる。腺体部の腺細胞は, 主 に, 中性多糖類 (PAS 陽性), 执よび, 蛋白質を含有して拈り，アリューシャン青にも弱染さ れ，少量だが酸性多糖類を産生している。腺頸部の腺細胞と舌粘膜上皮に点在している杯状細 胞は，中性および酸性多糖類を多量に含有しており，少なくとも今回用いた染色法では乍白質 は検出されなかった。脂質は, これらの腺細胞には含まれていない。 